\title{
Lymphoid follicles in antral mucosa: immune response to Campylobacter pylori?
}

\author{
M STOLTE, S EIDT \\ From the Institute of Pathology, Bayreuth Hospital, Bayreuth, West Germany
}

SUMMARY The prevalence of lymphoid follicles in endoscopic biopsy specimens from normal antral mucosa $(n=220)$, mucosa with reflux gastritis $(n=104)$, and in cases with Campylobacter pyloriassociated gastritis $(n=2544)$ was studied. In the latter group whether there were associations between degree and activity of gastritis and the prevalence of lymphoid follicles and between the occurrence of lymphoid follicles and the presence of intestinal metaplasia in the antrum were investigated. In cases with normal mucosa and in those with reflux gastritis lymphoid follicles were not detected, but mucosal lymphoid follicles were found in 1297 (54\%) of the cases with $C$ pyloriassociated gastritis. The prevalence of lymphoid follicles in the antral mucosa depended on the degree and activity of the gastritis and also correlated with the presence of intestinal metaplasia.

The development of lymphoid follicles in the mucosa of the antrum probably represents, primarily, an immune response to the colonisation of the mucosa by $C$ pylori.

While lymphoid follicles in the small intestine and colon are characteristic of a normal gastrointestinal tract, ${ }^{12}$ they are completely absent from the healthy stomach. ${ }^{1-4}$ Although their presence in the stomach in gastritis $^{35}$ or in the marginal areas of lymphomas ${ }^{6-8}$ has been repeatedly described both endoscopically and histologically, their pathogenesis is still unclear. In 1988 Wyatt and Rathbone' and our own working group $^{10}$ showed for the first time that hyperplasia of the lymphoid follicles apparently represents at least part of the response for Campylobacter pyloriassociated gastritis.

This study aimed at determining how often lymphoid follicle hyperplasia occurs in $C$ pyloriassociated antral gastritis, and whether these follicles can also be detected in normal antral mucosa and in reflux gastritis. Whether the prevalence of lymphoid follicles depends on the degree of lymphoplasmocellular infiltration or the activity of $C$ pyloriassociated gastritis, or both, and whether there is any correlation with intestinal metaplasia were also investigated.

\section{Material and methods}

Forceps biopsy specimens obtained from the antrum (at least two from each patient), stained with Accepted for publication 27 July 1989 haematoxylin and Warthin-Starry in three groups of patients with the following histological diagnoses were investigated. Group 1: antral mucosa showing no pathological changes $(n=220)$; group 2 : antral mucosa with the typical appearance of reflux gastritis $(n=104)$; group 3: antral mucosa with the typical appearance of $C$ pylori-associated gastritis $(n=2544)$.

Antral mucosa was defined as that showing no pathological changes when a normally structured mucosa with no evidence of infiltration by lymphocytes, plasma cells or polymorphonuclear leucocytes was found. Reflux gastritis was diagnosed in accordance with the criteria proposed by Dixon et al." Detection of $C$ pylori prompted the diagnosis of C pylori-associated gastritis. In this type of gastritis the degree of colonisation of antral mucosa by the organism, the degree of chronic gastritis, measured by the density of infiltration of the lamina propria by lymphocytes and plasma cells, and the degree of activity, measured by the density of infiltration with neutrophils, were assessed semiquantitatively in accordance with the criteria shown in the table. In the case of $C$ pylori-associated gastritis an attempt was made to establish whether the occurrence of lymphoid follicles correlated with the presence of intestinal metaplasia. The two main forms of intestinal metaplasia (incomplete and complete) were "pooled".

Statistical analysis was performed by the $\chi^{2}$ test. 
Table Degree and activity of gastritis and Campylobacter pylori colonisation

\begin{tabular}{|c|c|c|c|c|}
\hline & & Degree of gastritis & Activity of gastritis & C pylori colonisation \\
\hline I & Minimal & $\begin{array}{l}\text { Only very occasional, } \\
\text { uniformly distributed } \\
\text { lymphocytes and plasma } \\
\text { cells in the upper } \\
\text { lamina propria }\end{array}$ & $\begin{array}{l}\text { Occasional neutrophils } \\
\text { demonstrable in the } \\
\text { lamina propria }\end{array}$ & $\begin{array}{l}\text { Only minimal, focal } \\
\text { C pylori }\end{array}$ \\
\hline II & Low grade & $\begin{array}{l}\text { Uniform "loose" infiltration } \\
\text { of the upper lamina propria } \\
\text { by lymphocytes and plasma } \\
\text { cells }\end{array}$ & $\begin{array}{l}\text { Few neutrophils in the } \\
\text { lamina propria with no } \\
\text { leucopedesis in the region } \\
\text { of the gastric pits }\end{array}$ & $\begin{array}{l}\text { Few, uniformly distributed } \\
\text { C pylori }\end{array}$ \\
\hline III & Medium grade & $\begin{array}{l}\text { Moderately dense infiltration } \\
\text { of the upper lamina } \\
\text { propria by lymphocytes and } \\
\text { plasma cells }\end{array}$ & $\begin{array}{l}\text { Moderate numbers of neutrophils } \\
\text { in the lamina propria } \\
\text { with moderate leucopedesis in } \\
\text { the region of the gastric pits }\end{array}$ & $\begin{array}{l}\text { Moderately dense } \\
\text { colonisation }\end{array}$ \\
\hline IV & High grade & $\begin{array}{l}\text { Very dense lymphoplasmocellular } \\
\text { infiltration of the lamina } \\
\text { propria }\end{array}$ & $\begin{array}{l}\text { Abundant neutrophils in the } \\
\text { lamina propria with pronounced } \\
\text { leucopedesis and formation of } \\
\text { leucocyte "plugs" in the pits }\end{array}$ & $\begin{array}{l}\text { Very dense } C \text { pylori } \\
\text { colonisation }\end{array}$ \\
\hline
\end{tabular}

\section{Results}

In normal antral mucosa and in reflux gastritis antral mucosa (groups 1 and 2) lymphoid follicle hyperplasia was not seen. In $C$ pylori-associated gastritis, however, group 3, lymphoid follicle hyperplasia was detected in $1297(54 \%)$ of the cases.

The age distribution in the three groups shows that patients with normal antral mucosa or reflux gastritis were significantly younger than those with $C$ pyloriassociated gastritis (figure). In group 3, overall, however, there was no significant difference between the number of patients with and those without lymphoid follicles.

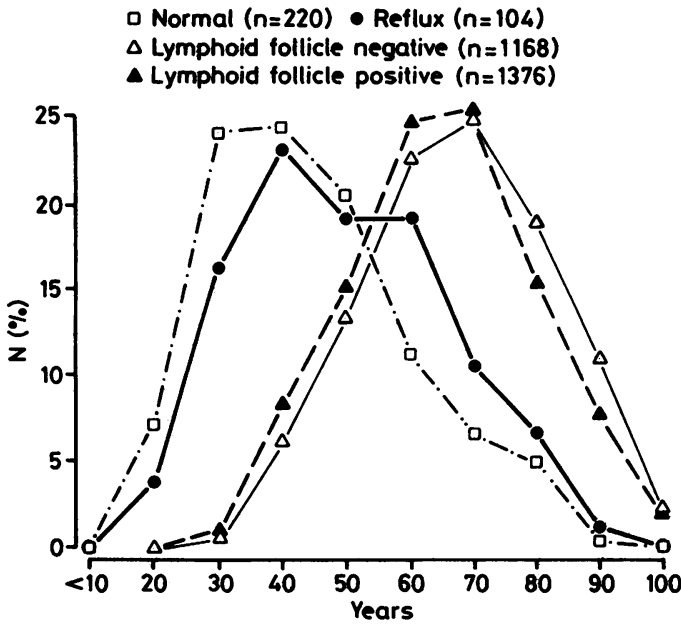

Figure Distribution of cases with normal antral mucosa ("normal"), reflux gastritis, Campylobacter-associated gastritis with no lymphoid follicle hyperplasia and Campylobacter-associated gastritis with lymphoid follicle hyperplasia.
An analysis of the prevalence of the lymphoid follicles in the antrum as a function of the degree of the C pylori-associated gastritis showed that with only minimal lymphoplasmocellular infiltration in the antral mucosa (but only four cases) no lymphoid follicles were found; in mild gastritis lymphoid follicles were seen in 21 of $103(22 \%)$ cases, in moderate gastritis in 948 of $1738(53 \%)$ cases, and in severe gastritis in 403 of $654(62 \%)$ cases. This correlation between the occurrence of lymphoid follicles and degree of lymphoplasmocellular infiltration of the lamina propria of the antral mucosa was highly significant, with a probability of error of less than 0.001 .

The prevalence of lymphoid follicles in the antrum also correlated significantly with the activity of gastritis $(p<0.001)$. In the absence of neutrophil infiltration lymphoid follicles were found in only eight of $93(8.6 \%)$, in cases with minimal infiltration in 27 of $82(33 \%)$, those with mild infiltration in 219 of 538 $(41 \%)$, and in those with moderate infiltration in 870 of $1372(63 \%)$, while the prevalence of lymphoid follicles in high grade activity gastritis again decreases somewhat to 251 of $459(55 \%)$.

When intestinal metaplasia was present in the antrum, lymphoid follicles were found in 334 of 532 $(63 \%)$ of these cases compared with 1042 of 2012 $(52 \%)$ of those with antral mucosa and no intestinal metaplasia. This difference was significant $(p<$ $0.001)$.

\section{Discussion}

In 1988 Wyatt and Rathbone pointed out that lymphoid follicles represent a relatively common feature of the histological picture of $C$ pyloriassociated gastritis. ${ }^{9}$ Before that, lymphoid follicles in the gastric mucosa had been represented endoscopically and histologically in a purely descriptive 
manner, ${ }^{512}$ with nothing being known about their pathogenesis. Prominent lymphoid follicle hyperplasia was designated lymphofollicular gastritis ${ }^{16}$ or pseudolymphoma. ${ }^{617}$ Other authors recognised the relation of the antral mucosa to gastritis, which they termed atrophic - without defining whether this really meant total atrophy of the antral mucosal glands. ${ }^{13}$ In this study, which was concerned with the difficult differential diagnosis between "pseudolymphoma" and malignant non-Hodgkin's lymphoma, the nature of the inflammatory infiltrates was not described, nor was anything said about colonisation by $C$ pylori. The high prevalence of lymphoid follicle hyperplasia of the antral mucosa described earlier by Wyatt and Rathbone ${ }^{9}$ is apparently often detectable in $C$ pyloriassociated gastritis. This is shown by our comparison between a group of normal subjects and a group of patients with reflux gastritis. No lymphoid follicle hyperplasia was detected in these two groups, while in C pylori-associated gastritis, it was present in $55 \%$ of the cases.

Analysis of the prevalence of lymphoid follicles as a function of the degree of gastritis showed a significant correlation: the more pronounced the gastritis, the more often was lymphoid follicle hyperplasia found. As the degree of gastritis depends on the severity of Cpylori colonisation of the mucosa,${ }^{14}{ }^{15}$ there is a direct relation, therefore, between the degree of $C$ pylori colonisation and the prevalence of lymphoid follicles in the antrum.

Lymphoid follicle hyperplasia was also correlated with the activity of the gastritis, which itself depends on the degree of colonisation by $C$ pylori. ${ }^{14}$ Surprisingly, the prevalence of lymphoid follicles associated with moderate neutrophil infiltration of the lamina propria was much greater than in massive neutrophil infiltration. This finding may be because in the group with gastritis and a pronounced polymorphocellular granulocytic component, colonisation of the gastric mucosa by $C$ pylori had been of a relatively short duration, so that lymphoid follicles had not had time to develop. Lymphoid follicles were detected more often in patients with intestinal metaplasia than in those without metaplastic changes. This may testify to the fact that the formation of lymphoid follicles is a consequence of relatively long standing $C$ pyloriassociated gastritis. Although the intestinal metaplastic mucosa itself is not colonised by $C$ pylori, this change is often only focal and the surrounding gastric epithelium shows infestation by the organism. In these cases a possible interpretation for the metaplastic foci could be previous transformation of these areas by an inflammatory process induced by $C$ pylori.

Overall, however, there was no difference in age distribution between the group of patients with $C$ pylori-associated antral gastritis with lymphoid follicle hyperplasia and those without. This, however, does not provide any indication as to the duration of $C$ pylori-associated gastritis. Although further immunohistochemical studies are still required, our results do seem to show quite clearly that the development of lymphoid follicles in the gastric mucosa is, in the first instance, probably an immune response to the colonisation of the mucosa by $C$ pylori.

\section{References}

1 Dukes C, Bussey HJR. The number of lymphoid follicles of the human large intestine. J Pathol Bacteriol 1926;29:111-6.

2 Morson BC. Colour atlas of gastrointestinal pathology. London: Harvey Miller, 1988.

3 Isaacson P, Wright DH. Extranodal malignant lymphoma arising from mucosa-associated lymphoid tissue. Cancer 1984;53: 2515-24.

4 Moore I, Wright DH. Primary gastric lymphoma-a tumour of mucosa-associated lymphoid tissue. A histological and immunohistochemical study of 36 cases. Histopathology 1984; 8:1025-39.

5 Demling L, Elster K, Koch H, Rösch W. Endoskopie und Biopsie von Speiseröhre, Magen und Zwölf-fingerdarm. Stuttgart: FK Schattauer, 1980.

6 Ranchod M, Lewin KJ, Dorfman RF. Lymphoid hyperplasia of the gastrointestinal tract. Am J Surg Pathol 1978;2:383-400.

7 Brooks JJ, Enterline HT. Primary gastric lymphomas. A clinicopathologic study of 58 cases with long-term follow-up and literature review. Cancer 1983;51:701-11.

8 Murayama H, Kikuchi M, Eimoto T, Doki I, Doki K. Early lymphoma coexisting with reactive lymphoid hyperplasia of the stomach. Acta Pathol Jpn 1984;34:679-86.

9 Wyatt JI, Rathbone BJ. Immune response of the gastric mucosa to Campylobacter pylori. Scand J Gastroenterol 1988;23(suppl 142):44-9.

10 Stolte M, Eidt S, Ohnsmann A. Campylobacter pylori: Unterschiedliche Auswirkungen auf die Magenschleimhaut. Vortrag beim 2. Münchner Campylobacter pylori-Symposium 1988. Stuttgart: Thieme, 1989 (in press).

11 Dixon MF, O'Connor HJ, Axon ATR, King RFJG, Johnston D. Reflux gastritis: distinct histopathological entity? J Clin Pathol 1986;39:524-30.

12 Rösch W, Fuchs H. Diffuse lymphatische Hyperplasie, Lymphom und Pseudolymphom des Magen-Darm-Trakts. Disch Med Wochenschr 1972;92:878-81.

13 Takaki K. Lymphoid follicles appearing in gastric mucosa, especially in reactive lymphoid hyperplasia and malignant lymphoma. Acta Pathol Jpn 1986;36:1627-41.

14 Stolte M, Eidt S, Ritter M, Bethke B. Campylobacter pylori und gastritis: Assoziation oder Induktion. Der Pathologie 1989; 10:21-6.

15 Steininger H, Schneider U, Bartz K, Simmler B. Campylobacter pylori und Gastritis-Besiede-lungsdichte und Grad der Entzündung. Semiquantitative und morphometrische Untersuchung. Leber Magen Darm 1989;19:70-7.

16 Konjetzny GE. Die Entzündungen des Magens. In: Henke F, Lubarsch $\mathrm{O}$, eds. Handbuch der Speziellen Pathologischen Anatomie und Histologie IV/2. Berlin: Springer Verlag, 1928: 872-3.

17 Tokunaga O, Watanabe T, Morimatsu M. Pseudolymphoma of the stomach. Cancer 1987;59:1320-7.

Requests for reprints to: Professor M Stolte, Klinikum Bayreuth, Preuschwitzer Strasse 101, 8580 Bayreuth, Federal Republic of Germany. 